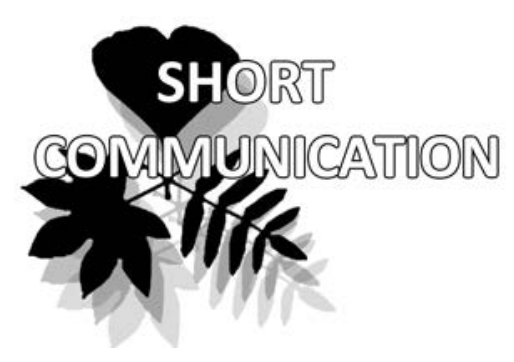

\section{Flow cytometry analysis of the relative content of nuclear DNA in Nitraria schoberi L. seeds}

\author{
Evgeny V. Banaev*, Mariya A. Tomoshevich \\ \& Mariya S. Voronkova
}

Evgeny V. Banaev *

e-mail: alnus2005@mail.ru

Mariya A. Tomoshevich

e-mail: arysa9@mail.ru

Mariva S. Voronkova

e-mail: bmc_87@mail.ru

Central Siberian Botanical Garden SB RAS, Novosibirsk, Russia

* corresponding authors

Manuscript received: 20.03.2018

Review completed: 05.05.2018

Accepted for publication: 18.05.2018

Published online: 19.05.2018

\begin{abstract}
A B S T R A C T
The effectiveness of using the flow cytometry method (FCM) to analyze the genome size of the genus Nitraria L. plants is discussed for the first time, a technique having been developed to study the relative nuclear DNA content in resting seeds of Nitraria schoberi L. The effect of adding polyvinylpyrrolidone antioxidant to the extracting buffer was studied to assess the presence of metabolites inhibiting nuclei staining with propidium iodide in leaves of a standard sample Raphanus sativus L. and N. schoberi seeds. The existence of inhibitors in leaves of the standard Raphanus sativus L. 'Saxa' was established. Intensity of fluorescence of nuclei isolated from $N$. schoberi seeds did not change under the antioxidant, indicating the absence of the staining inhibitor in the seeds. In addition, N. schoberi seeds are a convenient material for analysis of genome size, as they do not contain endosperm, are easily transported and easily stored.

K e y w o r d s : Nitraria schoberi, flow cytometry, genome size, relative DNA content
\end{abstract}

\section{P E 3 Ю M E}

Банаев Е.В., Томошевич М.А., Воронкова М.С. Особенности анамиза относительного содержания ядерной $\Delta$ НК в семенах Nitraria schobe$r i \mathrm{~L}$. методом проточной цитометрии. Впервые проведена оценка эффективности использования метода проточной цитометрии (FCM) Аля анализа размера генома растений рода Nitraria L., разработана методика исследования относительного содержания ядерной $\triangle$ НК в покоящихся семенах Nitraria schoberi L. Аیя оценки присутствия метаболитов, ингибирующих окрашивание ядер иодидом пропиАия, в Аистьях стандартного образца Raphanus sativus L. 'Saxa', и семенах N. schoberi проведено изучение влияния добавления антиоксиданта поливинилпиролилона в экстрагирующий буфер. Установлено наличие ингибиторов в Аистьях стандартного образца Raphanus sativus L. 'Saха'. Интенсивность флюоресценции ядер, выделенных из семян N. schoberi, не меняется под Аействием антиоксиданта, что свидетельствует об отсутствии в семенах ингибиторов окрашивания. Кроме того, семена N. schoberi явАяются удобным материалом Аля анализа размера генома, поскольку не содержат энАосперм, Аегко транспортируются и хорошо хранятся.

КАючевые слова: Nitraria schoberi, проточная цитометрия, размер генома, относительное содержание АНК
Plant cell nuclei contain hereditary information, which is why studies of nuclear DNA are of fundamental importance in solving complex biological questions. An effective method for estimating genome size is flow cytometry (FCM), successfully used in recent decades for assessing the genetic diversity of various plant organisms (Galbraith 2010); for solving taxonomic issues (Doležel et al. 2007, Loureiro et al. 2008, Rayburn et al 2009), questions regarding species evolution and dynamics (Bennett et al. 2005, Lee 2002, Loureir et al. 2010, Bennert et al. 2011), problems of natural hybridization (Price 1988, Kur et al. 2012, Winter et al. 2013, Hanusova et al. 2014), and polyploidy (Pecinka et al. 2006).

Plants of the genus Nitraria L. are typical halophytes, usually confined to intrazonal communities. In the view of Komarov (1908), the phylogenetic origin of this genus predates the formation of the desert belt along Gondwa- nan seacoasts in the Old World and Australia, and the slight morphological differentiation of species to the present day does not allow us to draw conclusions about their genesis. Populations of many Nitraria species are largely isolated from each other, which makes this genus a unique model for studying genetic differentiation.

The goal of this study was to develop a methodology for determining the genome size in seeds of Nitraria plants using FCM.

To estimate the genome size of N. schoberi, seeds were harvested on the shore of Lake Bagan in West Siberia $\left(53^{\circ} 53^{\prime} 54.54^{\prime \prime} \mathrm{N}, 77^{\circ} 8^{\prime} 33.60^{\prime \prime} \mathrm{E}\right)$, the natural habitat of Nitraria. As an internal standard we used fresh leaves of Raphanus sativus L. 'Saxa ${ }^{32}$ ' (2C DNA content $=1.11 \mathrm{pg}$ ) grown from seeds obtained from the Laboratory of Molecular Cytogenetics and Cytometry of the Institute of Experimental Bo- 
tany of the Academy of Sciences of the Czech Republic, in Olomouc-Holice (Doležel et al. 1992).

All flow-cytometric measurements were performed in the Central Siberian Botanical Garden of the Siberian Branch of the Russian Academy of Sciences (Novosibirsk). The analysis was carried out using a Cy Flow Space cytometer (manufactured by Sysmex Partec, Germany) with a laser radiation source of $532 \mathrm{~nm}$. The plant DNA content was determined by flow cytometry, staining isolated nuclei with propidium iodide $(\mathrm{PI})$.

A N. schoberi germ extracted from a seed was ground using a sharp blade together with an appropriate amount of the internal standard (Raphanus sativus L. 'Saxa' ${ }^{32}$ ) in $500 \mu$ l of a cooled extracting buffer (Nuclei Extraction Buffer) (Sysmex Partec) according to the manufacturer's protocol in Petri plastic cups. Samples were incubated at room temperature for two minutes.

The effect of adding polyvinylpyrrolidone (PVP) (Mw 29000) (Sigma-Aldrich, USA) antioxidant to the extracting buffer was studied to assess the presence of metabolites inhibiting nuclei staining with propidium iodide in N. schoberi seeds.

Four variations of the experiment were performed in three replications:

1. N. schoberi seed + standard sample Raphanus sativus L. 'Saxa' leaf + PVP.

2. N. schoberi seed + standard sample Raphanus sativus L. 'Saxa ${ }^{32}$ ' leaf with no added PVP.

3. Standard sample Raphanus sativus L. 'Saxa ${ }^{32}$ ' leaf + PVP.

4. Standard sample Raphanus sativus L. 'Saxa ${ }^{32}$ ' leaf with no added PVP.

After extraction of the nuclei the samples were filtered through a single-use Cellecrics Partec 50 micron Sysmex Partec filter, with the addition of $2 \mathrm{ml}$ of staining solution containing the staining buffer (Sysmex Partec) propidium iodide $(50 \mu \mathrm{g} / \mathrm{ml})$ and RNAse A $(50 \mu \mathrm{g} / \mathrm{ml})$. Staining occurred at room temperature in a dark location for 40 minutes. The prepared samples were stored in a refrigerator for no more than four hours.

For each sample 15,000 events were collected (with a required overall number of 5,000 to 20,000) (Galbraith et al. 1997). The relative nuclear DNA content was calculated based on the linear relationship between fluorescent signals from the stained nuclei of the studied samples, and the internal standard.

Basic statistics (mean, median, standard deviation) were calculated in $\mathrm{R}$ ( $\mathrm{R}$ Development Core Team 2011).

Analysis of the relative DNA content of $N$. schoberi seeds showed that with no PVP added to the extraction buffer, $2 \mathrm{C}$ values averaged $1.11 \pm 0.021$ higher in comparison with experiment variations adding PVP. This is due to the fact that in the absence of an antioxidant the fluorescence of the nuclei isolated from stan- dard leaf samples of Raphanus sativus L. 'Saxa ${ }^{32}$ ' decreases: G0/G1 and G2 peaks of the standard sample shift left by an average $2.5 \pm 0.043$ channels on a 256-channel scale, while the fluorescence intensity of nuclei isolated from $N$. schoberi seeds does not change under the antioxidant effect (Figure 1a, b).

Similar patterns were revealed in the experiment where only standard Raphanus sativus L. 'Saxa ${ }^{32}$ ' leaves were analyzed - with no added PVP a decrease in fluorescence of the nuclei was observed and, accordingly, G0/G1 and G2 peaks shifted left by the value indicated above (Figure 1c, d).

Although the flow cytometry method used to analyze genome size in plants was simple and reliable, one of the most difficult problems encountered by the FCM users was adjusting the buffer composition for species containing staining inhibitors such as phenols, caffeine and other secondary metabolites in leaf cells (Jedrzejczyk \& Sliwinska 2010). Notwithstanding the existence of research in this field (Price et al. 2000, Noirot et al. 2000, 2003), little information has been available to date on how stain inhibitors act, and there is no universal method to completely avoid their effect on assessment of DNA content in various organisms (Greilhuber et al. 2007, Greilhuber 2008). There is evidence that inhibition is associated with the intercalation of secondary metabolites in DNA and/or their direct reaction to a dye molecule, preventing its fluorescence (Loureiro et al. 2006, Loureiro et al. 2007). Adding antioxidants (polyvinylpyrrolidone, $\beta$-mercaptoethanol, dithiothreitol) to the buffer helps to rectify the situation; however, it does not always guarantee correct measurement of the DNA content, as the composition and concentration of secondary metabolites

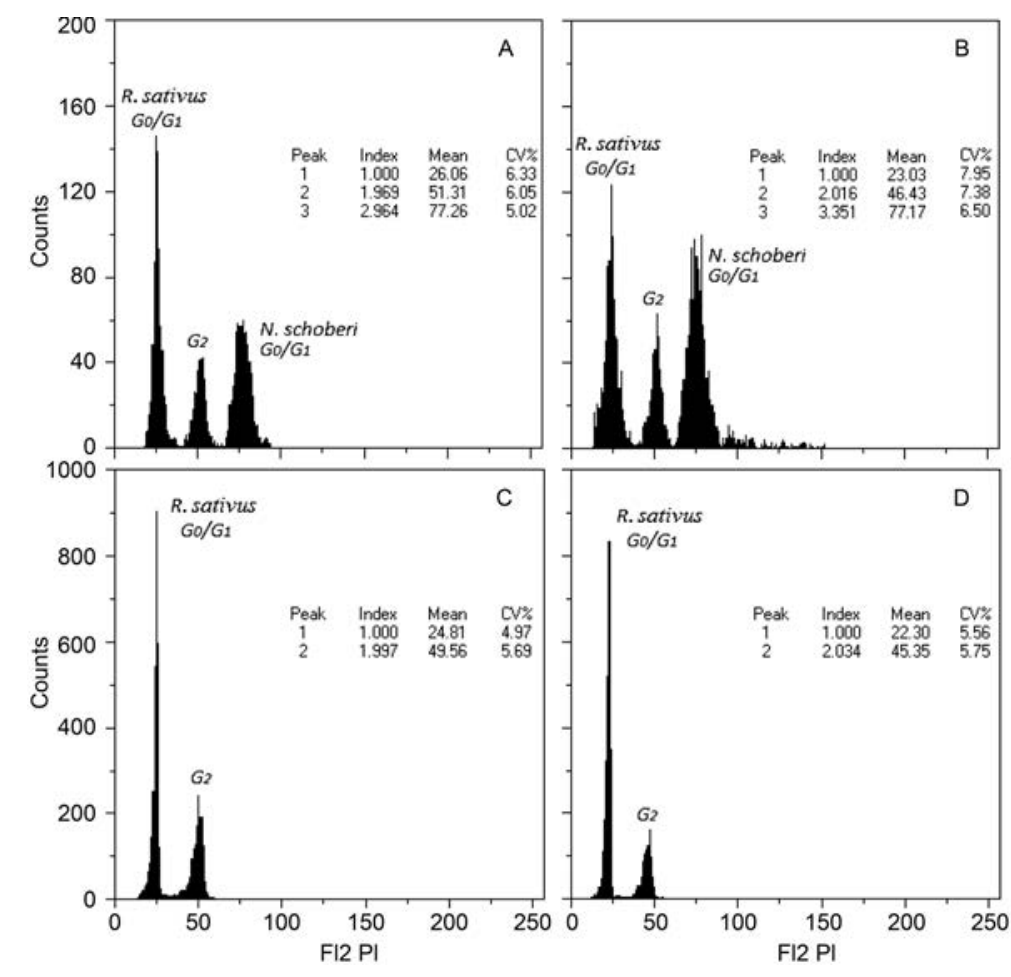

Figure 1 Histogram of PI fluorescence intensity: A - N. schoberi + standard Raphanus sativus L. 'Saxa' 2 ' PVP; B - N. schoberi + standard Raphanus sativus L. 'Saxa ${ }^{32}$; $\mathrm{C}$ - standard Raphanus sativus L. 'Saxa ${ }^{32}$ ' (with PVP addition); D -. standard Raphanus sativus L. 'Saxa' ${ }^{32}$ ' (without PVP addition) 
differ in various plant species and tissues (Yokoya et al. 2000, Sliwinska et al. 2005, Jedrzejczyk \& Sliwinska 2010).

In this regard, for analysis of genome size it is proposed to use, where possible, plant organs free of inhibitors, particularly seeds (Sliwinska et al. 2005, 2006, 2009), which have a number of advantages over leaf material in terms of accessibility for research, ease of transportation, and capability of being stored over a long term. Mature embryos of dormant seeds usually contain most of the cells in the G0/ G1 phase of the cell cycle (Sliwinska et al., 2009) and are thus suitable for determining the relative 2C DNA content. The presence of staining inhibitors should be checked for each species, especially woody ones, regardless of the plant material used for measurements, and the composition of buffer isolation nuclei should be optimized for plant species and their tissues (Jedrzejczyk \& Sliwinska 2010).

The characteristics we found of the decrease in fluorescence of nuclei isolated from the leaves of a standard sample of Raphanus sativus L. 'Saxa ${ }^{32}$, with no polyvinylpyrrolidone added to the extracting buffer, indicate the presence of staining inhibitors in leaves. The absence of shifts of G0/G1 peaks of N. schoberi on the histogram of PI fluorescence intensity is evidence of the absence of inhibitor substances in N. schoberi seeds.

Thus, N. schoberi seeds do not contain substances inhibiting PI nuclei staining; they are sufficiently large (up to $1.5 \mathrm{~cm}$ in length and $0.5 \mathrm{~cm}$ in diameter), have no endosperm, and are easily transported and stored, which makes them a convenient material for use in cytometric studies.

\section{ACKNOWLEDGEMENTS}

The study was supported in part by the Russian Foundation for Basic Research (grant 16-04-00631 to E.V. Banaev). We express our thanks to Steve Kohl for his assistance in preparing the article.

\section{LITERAT URE CITED}

Bennert, H.W, K. Horn, M. Kauth, J. Fuchs, I.S.B. Jakobsen et al. 2011. Flow cytometry confirms reticulate evolution and reveals triploidy in Central European Diphasiastrum taxa (Lycopodiaceae, Lycophyta). Annals of Botany 108: 867-876.

Bennett, M.D., I. Leitch \& T. Gregory 2005. Genome size evolution in plants. In: The Evolution of the Genome (T.R. Gregory, ed.), pp. 89-162. Academic Press, London.

Doležel, J., S. Sgorbati \& S. Lucretti 1992. Comparison of three DNA fluorochromes for flow cytometric estimation of nuclear DNA contrent in plants. Physiologia Plantarum 85: 625-631.

Doležel, J., J. Greilhuber \& J. Suda 2007. Estimation of nuclear DNA content in plants using flow cytometry. Nature Protocols 2:2233-2244.

Galbraith, D.W., G.M. Lambert, J. Macas \& J. Doležel 1997. Analysis of nuclear DNA content and ploidy in higher plants. In: Current protocols in cytometry, pp. 7.6.1-7.6.22. John Wiley \& Sons, NewYork.

Galbraith, D.W. 2010. Flow cytometry and fluorescence-activated cell sorting in plants: the past, present, and future. Biomedica 30:65-70.

Greilhuber, J. 2008. Cytochemistry and C-values: the lesswell-known world of nuclear DNA amounts. Annals of
Botany 101(6):791-804.

Greilhuber, J., E. Temsch \& J. Loureiro 2007. Nuclear DNA content measurement. In: Flow cytometry with plant cells: analysis of genes, chromosomes and genomes, (J. Doležel, J. Greilhuber \& J. Suda, eds), pp. 67-101. Wiley VCH, Weinheim.

Hanusova, K., L. Ekrt, P. Vit, F. Kolar, T. Urfus 2014. Continuous morphological variation correlated with genome size indicates frequent introgressive hybridization among Diphasiastrum species (Lycopodiaceae) in Central Europe. PLOS ONE 9:1-13.

Jedrzejczyk, I. \& E. Sliwinska 2010. Leaves and seeds as material for flow cytometric estimation of the genome size of 11 Rosaceae woody species containing DNA-stating inhibitors. Journal of Botany, article ID 930895, pp. 1-9.

Komarov, V.L. 1908. Introduction to the floras of China and Mongolia. Trudy Sankt-Peterburgskogo botanicheskogo sada 19:1-179 (in Russian) [Комаров В.А. 1908. Введение к флорам Китая и Монголии // Тр. Санкт-Петерб. Ботан. сада. Т 19. С. 1-179].

Kur, P., M. Stech, P. Koutecky \& P. Travnicek 2012. Morphological and cytological variation in Spergularia echinosperma and $S$. rubra, and notes on potential hybridization of these two species. Preslia 84:905-924.

Lee, C.E. 2002. Evolutionary genetics of invasive species. Trends in Ecology \& Evolution 17:386-391.

Loureiro, J., E. Rodriguez, J. Doležel \& C. Santos 2006. Flow cytometric and microscopic analysis of the effect of tannic acid on plant nuclei and estimation of DNA content. Annals of Botany 98(3):515-527.

Loureiro, J., J. Dolezel, J. Greilhuber, C. Santos \& J. Suda 2008. Plant flow cytometry - far beyond the stone age. Cytometry A 73(7):579-580.

Loureiro, J., E. Rodriguez, Â. Gomes \& C. Santos 2007. Genome size estimations on Ulmus minor Mill., Ulmus glabra Huds., and Celtis australis L. using flow cytometry. Plant Biology 9(4):541-544.

Loureiro, J., P. Travnicek, J. Rauchova, T. Urfus et al. 2010. The use of flow cytometry in the biosystematics, ecology and population biology of homoploid plants. Preslia 82: 3-21.

Noirot, M., P. Barre, C. Duperray, J. Louarn \& S. Hamon 2003. Effects of caffeine and chlorogenic acid on propidium iodide accessibility to DNA: consequences on genome size evaluation in coffee tree. Annals of Botany 92(2):259-264.

Noirot, M., P. Barre, J. Louarn, Ch. Duperray \& S. Hamon 2000. Nucleus-cytosol interactions - a source of stoichiometric error in flow cytometric estimation of nuclear DNA content in plants. Annals of Botany 86(2):309-316.

Pecinka, A., P. Suchánková, M.A. Lysak, B. Trávníček \& J. Doležel. 2006. Nuclear DNA content variation among Central European Koeleria Taxa. Annals of Botany 98(1):117-122.

Price, H.J., G. Hodnett \& J.S. Johnston 2000. Sunflower (Helianthus annuus) leaves contain compounds that reduce nuclear propidium iodide fluorescence. Annals of Botany 86(5):929-934.

Price, H.J. 1988. Nuclear DNA content variation within angiosperm species. Evolutionary trends in plants 2:53-60.

Rayburn, A.L., J. Crawford, C.M. Rayburn \& J.A. Juvik 2009. Genome size of three Miscanthus species. Plant Molecular Biology Reporter 27:184-188.

Sliwinska, E. 2006. Nuclear DNA content analysis of plant seeds by flow cytometry. Current Protocols in Cytometry, pp. 7.29.1-7.29.13. John Wiley \& Sons, NewYork.

Sliwinska, E. 2009. Nuclear DNA replication and seed quality. Seed Science Research 19(1):15-25. 
Banaev et al.

Sliwinska, E., E. Zielinska \& I. Jedrzejczyk 2005. Are seeds suitable for flow cytometric estimation of plant genome size? Cytometry A 64(2):72-79.

Sliwinska, E., I. Pisarczyk, A. Pawlik \& D.W. Galbraith 2009. Measuring genome size of desert plants using dry seeds. Botany 87(2):127-135.

Winter, S., R. Chizzola, M. Kriechbaum \& M. Kropf 2013. Hybridisation in Jacobaea - characterisation of hybrids be- tween Jacobaea aquatica and J. vulgaris in Austria. Plant Ecology \& Diversity 6:217-229.

Yokoya, K., A.V. Roberts, J. Mottley, R. Lewis \& P.E. Brandham 2000. Nuclear DNA amounts roses. Annals of Botany 85(4):557-561. 